\title{
Decoupling urban transport from GHG emissions in Indian cities A critical review and perspectives
}

Jun Li

CIRED

\begin{abstract}
How to sustain rapid economic and urban growth with minimised detriment to environment is a key challenge for sustainable development and climate change mitigation in developing countries which face constraints of technical and financial resources scarcity as well as dearth of infrastructure governance capacity. This paper attempts to address this question by investigating driving forces of transport demand and relevant policy measures that facilitate mitigating GHG emissions in the urban transport sector in Indian cities based on a critical review of the literature. Our overview of existing literature and international experiences suggests it is critical to improving urban governance in transport infrastructure quality and developing efficient public transport, coupled with integrated land use/transport planning as well as economic instruments. This will allow Indian cities to embark on a sustainable growth pathway by decoupling transport services demand of GHG emissions in the longer term. Appropriate policy instruments need to be selected as to reconcile the imperatives of economic and urban growth, aspiration to higher quality of life, improvements in social welfare , urban transport-related energy consumption and GHG emissions mitigation target in Indian cities.
\end{abstract}

Keywords: India, urban transport, GHG mitigation 


\section{Introduction}

Transport plays an important role in addressing the challenges of climate change mitigation as it consumes nearly half of global oil and contributes one-quarter of total fossil fuel-combustion related CO2 emissions of the world (IEA, 2010b). In 2004, the transport sector is responsible for $14 \%$ of anthropogenic greenhouse gas emissions and $17 \%$ of global $\mathrm{CO}_{2}$ emission (WRI, 2008; IPCC, 2007) ${ }^{1}$, of which on-road transport represents more than $90 \%$ globally. Transport demand and related emissions in the world would increase significantly over the next decades in the business as usual (BAU) scenarios according the estimates in a number of studies (Fig. 1), in which both bottomup and top-down modelling methodologies were used. In a recent paper published in PNAS, Unger et al. (2010) argue that motor vehicles have emerged as the greatest contributor to atmospheric warming now and in the near term. More specifically, the authors stress the fact that transport growth-related economic and environmental impacts might inhibit services to enable economic growth in the next decades if unchecked. Clearly, these prospects for transport pose a great challenge to achieve the 2-degree climate target which was confirmed again at the recent Cancun UNFCCC conference. On the other hand, mitigating emissions from road transport sector is particularly attractive because this action yields both rapid and long-term climate benefits, as well as co-benefits for human health².

With its leapfrogging economy, India has become a major energy consumer and GHG emitter in Asia. While India undergoes fast economic growth and profound societal transformation, energy consumption and GHG emissions in the transport sector could increase exponentially given the scale of urban expansion and continued quest of higher living standards if no drastic policies were undertaken appropriately and timely. Motorised traffic volume in India would reach 130000 billion passenger-km (92\% on-road transport), resulting in a 5-fold increase in energy demand and carbon emissions in transport by 2020 relative to 2000 under the current trend (Singh, 2006).

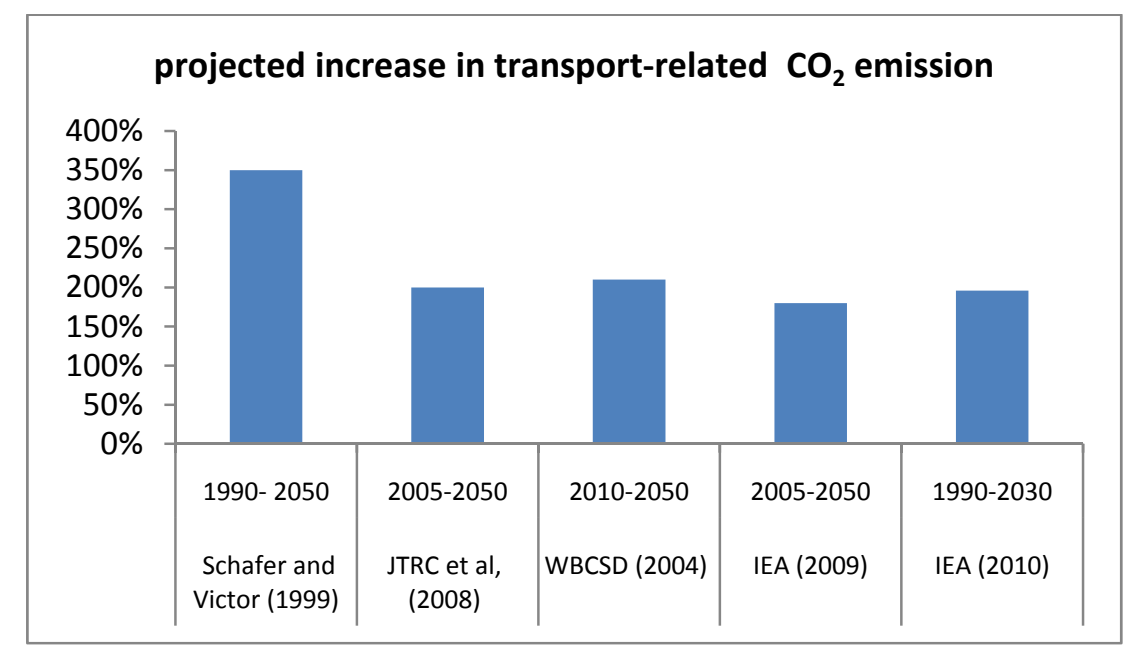

Figure 1 Estimates of global CO2 emissions from transport sector in different studies

Specifically, the scope for fuel substitution is relatively small even though the renewable transport fuels will have to account for a share in the fuel supply, but only to a limited degree in the foreseeable future. Globally, transport energy is over 95\% dependent on oil. As in most countries, transport in India mainly consumes nonrenewable fuels and contributes to CO2 emissions. In 2005-2006, the transport sector in India consumes about $17 \%$ (36.5 mtoe) of the country's total energy (217 Mtoe), energy sources used in this sector are coal, diesel, petroleum (gasoline) and electricity (Ramachandra and Shwetmala, 2009).

Currently, most transport-related emissions are concentrated in urban areas which account for the bulk of onroad transport energy consumption. It is foreseeable that most increase in carbon emissions in rapidly developing countries like India will come from cities as a result of unprecedented urbanisation and motorization, which in turn is determined by the urban transport policy and governance structure. In the meantime, India is

\footnotetext{
${ }^{1}$ In some areas of the world the percentage is much higher. For example in California, transport accounts for more than $40 \%$ of the state's annual greenhouse gas emissions (California State Government, 2007).

2 As mentioned in Colvile et al. (2001), road traffic exhaust emissions have been the cause of much concern about the effects of urban air quality on human health and tropospheric ozone production.
} 
urbanising rapidly, more than 250 million people will come to live in Indian cities by 2030 (UNEP 2007, Mckinsey, 2010). Over the period 1991-2005, energy consumption from urban transport in 23 major urban areas (million-plus cities) in India more than doubled, growing from 103 to 209 PJ, whilst carbon emissions increased from 7.9 Mt to $15.3 \mathrm{Mt}$. Consequently, transport infrastructure provisions in cities will play an increasingly important role in GHG mitigation in India in the next decades given the spectacular pace of urban development, growing aspiration to private car ownership and required resources to meet the constantly growing demand.

Private car ownership in many large Indian cities increased significantly and dominates the car use in rural areas. According to the Reddy and Balachandra (2010), per capita travel by cars in 23 urban areas was 331 pkm in 2005, in particular in the city of Delhi which recorded a markedly high level of 894 P-km in 2005, whereas the national average of car use per capita was only $58.6 \mathrm{pkm}$ in the same year. Therefore, the way Indian cities develop their urban infrastructure today will shape the pathway of energy demand and carbon emissions for several decades, and wrong decisions must be avoided to minimise the risk of carbon lock-in.

Nonetheless, exploiting technological progress potentials such as improvements in fuel economy and alternative fuels alone may not provide the 'one-fit-all' answer to GHG mitigation in the transport sector, policies and economic instruments influencing consumer preferences and lifestyles are also needed (Michaelis and Davidson, 1996). Besides technical aspect, energy consumption and related GHG emission in urban transport are also heavily influenced by urban development policies in relation to land use and public transport organization (Kenworthy, 2003).

Due to the strong inertia and long lifetime, failure in implementation of energy efficient and low-carbon transport will risk locking in irreversible carbon-intensive mire and would entail huge social costs in fast developing cities during the entire operating stage. This means that environmental quality of the transport infrastructure built now will determine the level of energy consumption and GHG emissions of the cities for decades. Thus a key question arises about how to meet the growing demand while minimising environmental impacts during the urban growth process. The purpose of this paper is to address this question and outline relevant strategies from the perspective of large-scale urban infrastructure governance in Indian cities, based on a critical review of key findings and advancement in recent literature on urban transport policies.

\section{Energy policies in India}

\subsection{Raison d'être of reconciling urban growth and environment in India}

India is facing various challenges in its socioeconomic development priorities : poverty reduction, urban growth and infrastructure provision, environmental quality, security of energy supply and climate change mitigation and adaptation. Stimulated by fast economic development, the next few decades will see an unprecedented scale of urban growth in India's metropolitan area. India's current urbanisation rate is still low, only 30\% in 2008 (World Bank, 2010), but is increasing rapidly. It is projected that India will take over China to become the most populous country by 2030 and urban population will double then in India with more than 320 million rural residents migrating to the cities during 2000-2030 period (UNDP, 2007), implying a huge potential for increase in demand for urban infrastructure, and transport in particular in the next decades.

Over the past two decades, resources consumption in India has risen steadily to fuel the industrialization and to meet the growing living standards of people, as a result of fast economic development and urbanisation. Figure 2 delineates the past trend of increase in fossil fuels consumption (carbon emissions follow similar trends implicitly) in India and other regions in the world. Together with China, fossil fuels consumption in India increased significantly since its economic reforms in early 1990s. 


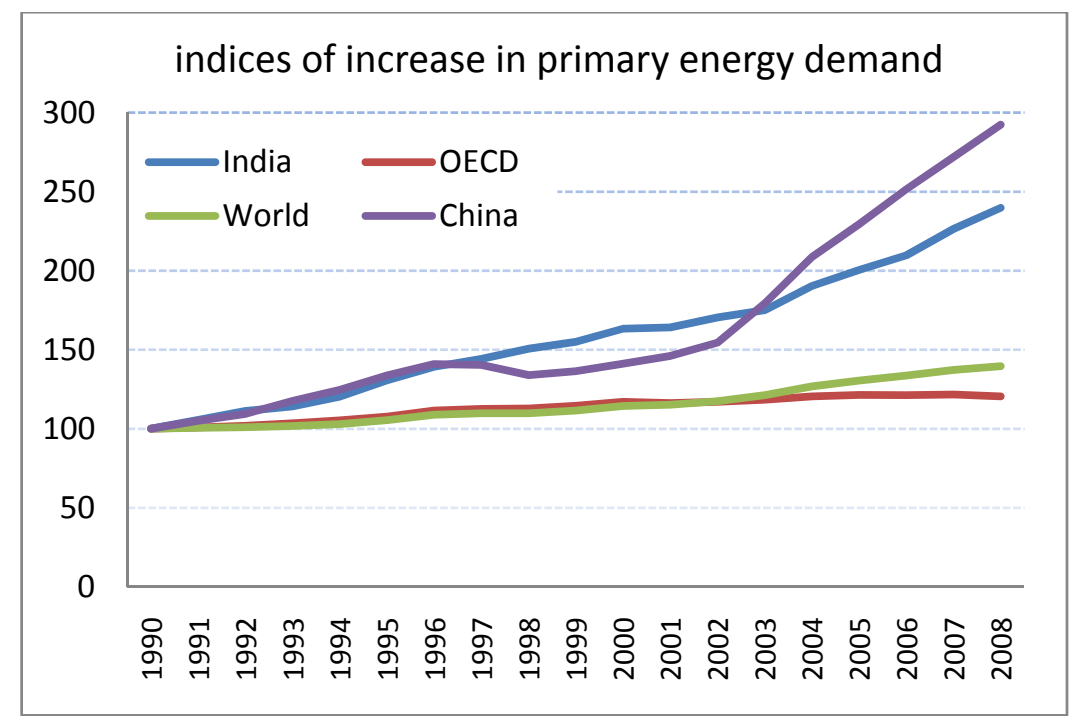

Figure 2 indice of increase in fossil fuels consumption $(1990=100)$ Source : BP 2009; IEA 2009

In 2007, India consumed 595 mtoe energy and energy-related $\mathrm{CO}_{2}$ emissions reached $1324 \mathrm{Mt}$, ranking India the $5^{\text {th }}$ major GHG emitter in the world (Indian Ministry of Environment, 2009). Meanwhile, per capita emission increased more than three times whilst total population increased only $60 \%$ over the same period (IEA, 2009; US Census Bureau, 2009).

In a recent study, Azomahou et al. (2006) employ a nonparametric approach to showing that the per capita $\mathrm{CO}_{2}$ emission in India is following upward trend with respect to economic development ${ }^{3}$. Likewise, the high $\mathrm{CO}_{2}$ emission-urbanisation elasticity in low-income countries found in an empirical study conducted by Martínez-Zarzoso (2008) underlines the importance of the role of public policies in decoupling urbanisation from sharp increase in $\mathrm{CO}_{2}$ emissions in India.

\subsection{Transport and security of energy supply}

Currently, 70\% of oil consumption in India is dependent on imports; and it would surpass Japan to become the third-largest oil importer soon after 2020 (IEA, 2009). The constant volatility and escalating prices and geopolitical ramifications render it particularly vulnerable with respect to security of supply. Note that policy responses to energy security are not necessarily the same of climate change. For example, coal-to-liquids and biofuels may reduce energy dependence but may do nothing or little for climate change (including emissions associated with land use change, fuels production and distribution). In addition, developing crop-derived biofuels in developing countries also raises the concern about food security. India is constrained by available land for biofuels feedstock supply. Studies show that there is only limited scope for increasing agricultural land area in India, and using available arable land to cultivate dedicated energy crops for biofuels production is critical given the extremely high pressure on food supply security (IEA, 2010b) ${ }^{4}$.

Another future perspective of clean technology in the transport sector is to introduce hydrogen and fuel cell. Recent papers outline the roadmap and perspective of scaling up hydrogen towards sustainable energy supply pathway. However, the high cost is a major barrier to commercial-scale deployment of hydrogen in transport to substitute for fossil gasoline and diesel. Moreover, Soloman and Banerjee (2006) point out in their review study on global hydrogen energy economy that hydrogen will be primarily produced from fossil fuels in most country cases in the mid-term, thus the underlying sustainability issues of hydrogen supply should be taken with a grain of salt.

\footnotetext{
${ }^{3}$ Statistically significant at 5\% level, countries like India and China are pursuing the upwind trend of per capita $\mathrm{CO}_{2}$ emission as per capita GDP increases(Azomahou et al., 2006).

${ }^{4}$ The climate change will exacerbate the food security with negative impact on agricultural production in India (IPCC, 2007). More than one-fifth of Indian population was undernourished in 2004-2006 and there still exist a large number of poor people ${ }^{4}$ in India (FAO, 2003; IFPRI, 2009; World Bank, 2010).
} 


\section{Urban transport/ urban form nexus}

Energy demand in transport sector is determined simultaneously by both technical and socioeconomic parameters, such as demography, household structure, urban form (e.g. density), infrastructure and mode of transport (mass transit system and public transport supply) available, income, fuel price etc. likewise, Individual travel behaviour, such as driving a car or commuting in public transit for travel purpose, is also strongly influenced by different socioeconomic factors (income, education, employment, fuel price, residential neighbourhood )as well as urban structure ( location of jobs, accessibility and quality of service of public transit system, urban density etc).

Public transport policies may also affect the private car use as urban development policy can have significant impact on private transport modes and resultant carbon emissions. Apart from income, the factors favouring increased car ownership and use, such as more dispersed residences and work places as well as more complex trip patterns, are strong and very difficult to change through policy interventions (Short, 2008).

The form of urbanization turns out to be one of key determining factors for energy demand as well as GHG emissions in cities. Various literatures on land use and transport policies in cities provide insightful views on the relationship between urban development policy and transport in both developed and developing nations (e.g. Newman, 1993; Handy, 1996; Burton 2000; Shim et al., 2006). In particular, empirical studies show that urban expansion is generally associated with increased demand for electricity and energy of households, increasing density could significantly reduce energy consumption and carbon emissions of transport (OECD 2009) .

Despite remarkable improvements in fuel efficiency, energy demand in transport sector keeps growing rapidly in rich countries ${ }^{5}$. Fuel efficiency improvement has been partly offset by increased displacement distance and car use frequency (rebound effect), and urban sprawl is one of the major factors that drive up private car use and subsequent transport energy consumption in many industrialised countries (EEA, 2006; OECD, 2008). For example, the sprawling growth resulted in fast expansion of suburban area and encouraged the use of privates in vast majority of OECD counties over the past decades. Since the 1950s, European cities have spread on average by $78 \%$, while their population has increased by only $33 \%$ (Kasanko et al., 2006). Insofar as American cities are concerned, during 1960-1990 period, the amount of developed land in metropolitan areas in the US more than doubled, while population grew by less than half (Song and Zenou, 2006). This phenomenon, enabled by the mass ownership of cars, causes ever-increasing private transport needs. The sprawling pattern of urban growth has also been observed in developing countries over the past decades, including Indian cities (Schneider and Woodcock, 2008).

Urban planning, in particular the land use policy, plays an important role in shaping city's structure, and subsequently, the demand for transit or private cars. Various literatures indicate that increasing urban density reduces significantly per capita vehicle travel (Newman et al., 1997; Kenworthy and Laube, 1999; Kenworthy, 2003; Mindali et al., 2004) and results in lower fuel consumption and transport-related greenhouse gas emissions. Table 1 recapitulates the findings in recent literature on the relationship between urban form and transport (automobile) energy demand in different cities across the world, both qualitative and econometric approaches were used in these studies. We can see that most studies confirm the strong relationship between urban form and transport energy demand.

Table 1 Empirical results of the relationship between urban form and transport energy demand as well as car use

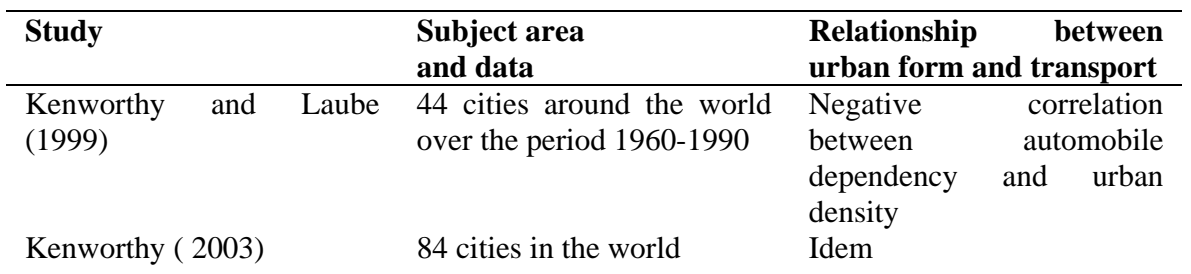

\footnotetext{
${ }^{5}$ For example, the US introduced the CAFÉ standard in 1975; and the fuel economy of private passenger cars in the US improved remarkably over the past 3 decades, increasing from 13.5 to 31.2 miles per gallon during 1975-2008, however, fuel consumption of LDVs in the US grew over $42 \%$ during the same period due to increased LDV population and average driven distance (BTS, 2010; EIA 2010).
} 
Mindali et al.( 2004)

Glaeser and Kahn (2004)

Bento et al.( 2005)

Shim et al. (2006)

Vance and Hedel (2007)

Grazi et al.(2008)

Karathodorou et al. (2010)
Data in Kenworthy (1989), 32 major cities in four continents

131 major MSAs in US ; 70 international cities

114 urban areas in the US

small- and medium-sized cities in Korea

Panel data of daily travel in Germany 1996-2003
No direct impact of urban density on transport energy demand positive correlation between low-density cities (what we call sprawl) and car ownership

City shape, road density , population centrality have significant effect on annual household VMTs

High density and population concentration decrease transport energy consumption

Causative impact of urban form on car use (urban form is a statistically significant determinant of automobile use)

Dutch Housing Survey Significant impact of urban 1998, density on private car 458 municipalities in the ownership and driving Netherlands

Millennium Cities Database for Sustainable Transport (1999); 84 cities from 42 different countries distance

Urban density affects fuel consumption, mostly through variations in the car stock and in the distances travelled

On the other side of the debate some critiques prevail on Newman and Kenworthy's hypothesis wherein there exists strong correlation between urban density and car use and fuel consumption ${ }^{6}$. Nonetheless, empirical studies show that there exist strong relationships between car ownership, car-related fuel consumption and urban in cities (Bento et al., 2005; Vance and Hedel, 2007; Grazi et al., 2008; Karathodorou et al., 2010; Kenworthy and $\mathrm{Hu}, 2002$ ), and support the hypothesis of negative correlation between urban density and car use, travelled distance of vehicle, fuel demand, and commuting-related carbon emissions, both in developed and developing nations (Johansson and Schipper, 1997; Glaeser and Kahn, 20047 ; Shim et al., 2006; Grazi et al., 2008; Karathodorou et al.,2010).

The increase in household income and continuous pursuit of western way of life has been and will still be the main propelling factor to drive up private car ownership and fuel consumption. However, In fact, the dynamics between urban structure such as road infrastructure and transport energy consumption is considerably complicated. Investment in road infrastructure is largely a response to the growth in car ownership; the growing demand resulting from increased car ownership is driving road infrastructure further. Improved infrastructure is also pushing up demand for cars - which, in turn, makes it attractive to purchase new cars. As indicated in Reddy and P. Balachandra(2010), although higher vehicle ownership is a consequence of increasing affluence, it is also driven by urban structure and the need for private motorised mobility in the absence of good-quality public transport infrastructure. Urban form has also contributed to the growth in vehicle use, particularly in emerging cities such as Bangalore and Hyderabad whereas cities like Mumbai and Chennai have a clear urban structure with efficient public transportation system, where average urban vehicle density is far lower than emerging cities (vehicle density is 2841/sq.km in Bangalore and 661/sq.km in Kolkata).

\footnotetext{
${ }^{6}$ Most critiques include the lack of control for variables that may affect fuel consumption such as gasoline price regime, income, local transport policy (e.g., road condition, public transport supply, accessibility of mass transit system) as well as lack of multivariate analysis. Moreover, the indirect effects of income, such as its effects on density were overlooked in their analysis, in other words, urban density variation may result endogenously from the change in income distribution of local residents (Karathodorou et al., 2010).

${ }^{7}$ Specifically, Glaeser and Kahn (2004) argue that urban sprawl in US cities has been produced as a inexorable product of car-based living rather than bad urban planning or explicit government policies. However, situation in European cities turn to be different, as indicated in Grazi (2008), EU countries, urban density is strongly determined by national policy.
} 
In the automobile cities, dense urban development pattern tend to have influences on driving pattern and energy consumption of cars. The main drivers of fuel consumption of private cars can be derived through decomposition approach that initiated by Baltagi (1983). The cross-country study of Karathodorou et al. (2010) suggests the urban density influences fuel consumption mostly through the car ownership and the distances travelled by car, whereas it has insignificant impact on the fuel consumption per km (technical improvement in terms of gain in fuel economy of cars). This may be explained by two countervailing factors :1. high-density urban structure encourages the purchase of smaller car (due to parking constraints)with better fuel economy; thus reducing fuel consumption per travelled distance; 2 . denser cities slow down the average traffic and result in more frequent 'stop-and-go' driving pattern with increased fuel consumption and emissions per km travelled. This means that globally, higher performance of transport in cities with high-density exceeds the loss of efficiency associated with congestion, this finding is consistent with Newman and Kenworthy (1988).

\section{Key challenges facing transport in Indian cities}

\subsection{Urbanisation and transport demand}

It is foreseeable that the vast majority of increase in transport demand in India over the coming decades will come from cities as the result of urbanisation. Experiences in the past show that economic growth has been accompanied by increased urban development and sustained economic growth cannot take place without the urbanisation process (Henderson, 2010). In many developing countries, economic activities are highly concentrated in large cities. For instance, with less than 30\% of total population, the 53 largest Chinese metropolitan regions produced almost two-thirds of Chinese GDP in 2007(OECD, 2009). Similar situation can also be found in India. Mumbai, India's commercial capital, with only $1 \%$ of total population, produced $17 \%$ of Indian GDP, contributes 25 per cent of industrial output and 70 per cent of capital transactions to India's economy in 2009(PWC, 2010). More specifically, the metropolitan cities will be the main drivers of energy demand in transport sector over the next decades. Bose et al. (2001) examine the transport-related GHG emissions trend in Delhi, one of the most representative metropolitan cities in India where urban transport has been developing at break-neck speed. Delhi's population grew from 1.7 million in 1950 to 13 million in 2001, leading to extensive road network and high vehicle ownership rate today (around one-fifth of Delhi population). Travel had doubled between 1990 and 2000. Their results show that intra and inter-urban transport-related energy consumption in 2020 would double that in 2000 under the BAU scenario. The foremost challenge of GHG control in the transport sector will be relying on small scooters/motorcycles and cars, accounting for $50 \%$ and $25 \%$ of total vehicles, respectively.

\subsection{Exponential growth of motor vehicles in urban transport and}

In 2006, the 800 million light-duty vehicles (LDVs, including automobiles, light trucks, SUVs and mini-vans) around the world accounted for about $47 \%$ of transport energy use (IEA 2009). In the meantime, the number of vehicles in Indian cities increased sharply following the globalization and liberalisation in 1980s(Ramachandra and Shwetmala, 2009). Singh et al. (2008) highlight that gasoline and diesel consumption for road transport in India have quadrupled between 1980 and 2000 due to about nine-fold increase in the number of vehicles and evergrowing passenger travel demands. A recent study conducted by the Asian Development Bank shows that a combination of accelerating incomes, urban growth, and expanding vehicle ownership would run the risk of severely constraining the future economic advancement of Indian cities (ADB, 2006). According to their projection, the number of cars and sport utility vehicles (SUVs) in India could reach 13 times the present level to stand at around 80 million vehicles and the population of motorcycles could reach 236 million in 2035 under the BAU scenario. Total fuel consumption of on road vehicles in India in 2035 will be over six times that in 2005. Accordingly, carbon dioxide emissions from on-road transport can be expected to rise by nearly 6 times in India over the same period . The sharp increase in oil consumption in India's transport sector will certainly raise the concerns about GDP loss, the security of energy supply and GHG emissions. Importantly, motorised mobility (mainly including cars, motorised two-wheelers, auto-rickshaws, buses and railways) increased significantly in the past decades, in particular in urban areas of India. the vehicle population in India has increased by about 15 times, from 5.36 to 81.5 million vehicles, whereas the population has increased just by 1.7 times between 1981 and 2005. The 23 large and medium urban centres accounted for about $28.5 \%$ of these vehicles in 2005, even though their population comprised only about $9.5 \%$ of the total (Reddy and Balachandra ,2010). 
The growing vehicle ownership in India is fuelled by sustained economic growth and rising incomes over the last three decades. The increasing vehicle ownership is a key factor underlying the road construction and rapid traffic growth. The population of motor vehicle has risen sharply since 1981 with more than 16-fold increase by 2006 (Fig.4). More specifically, two-wheelers account for a significant part of increased motorized transport in Indian cities, representing about $72 \%$ of total vehicle stock, whereas buses only account for $1 \%$. Most buses are run by private sectors (88.7\%). India alone accounts for roughly $20 \%$ of the world's fleet of two-wheelers second only to China, and motorized two-wheelers account for $80 \%$ of the total motorization rates in Chennai and $50 \%$ in Mumbai (WBCSD, 2004). Addressing the environmental effectiveness of these two- and threewheelers without compromising mobility demand in Indian cities is a daunting challenge for the decades to come.

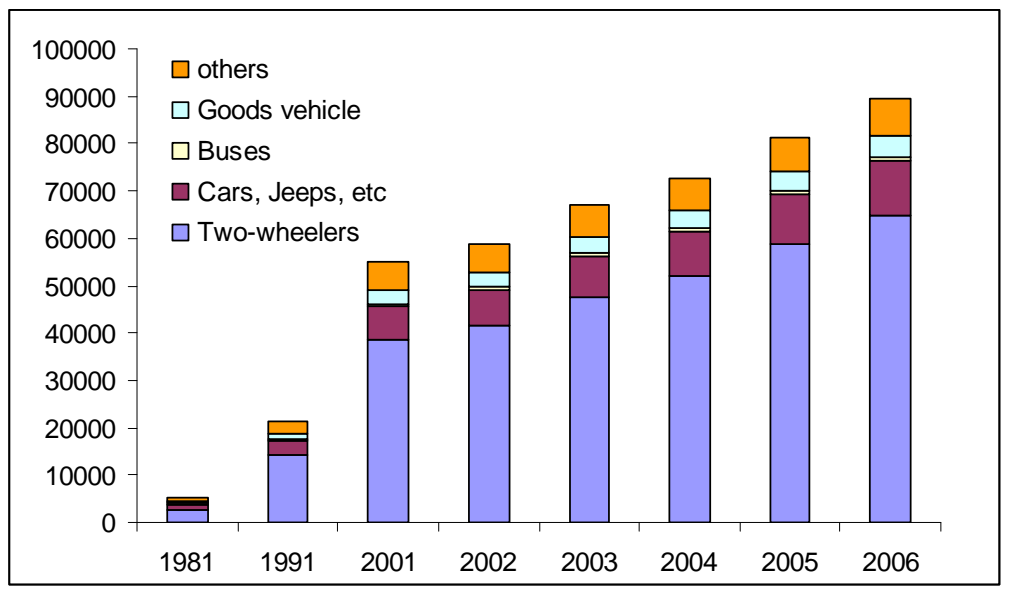

Note: Three wheelers, Auto-rickshaw, Tractors, etc are included in others

Figure 3 Motor Vehicle population growth in India ( Source : Ministry of Road, Transport \& Highways, 2009)

As can be seen in Fig.3, most increase in vehicles in India are M2W and cars, energy efficiency of car, twowheelers and auto-rickshaw is generally poorer in terms of fuel consumption per passenger per kilometre (Figure $4)$, as their load factor $(\mathrm{p} / \mathrm{Km})$ is much lower than buses and other mass transit systems.

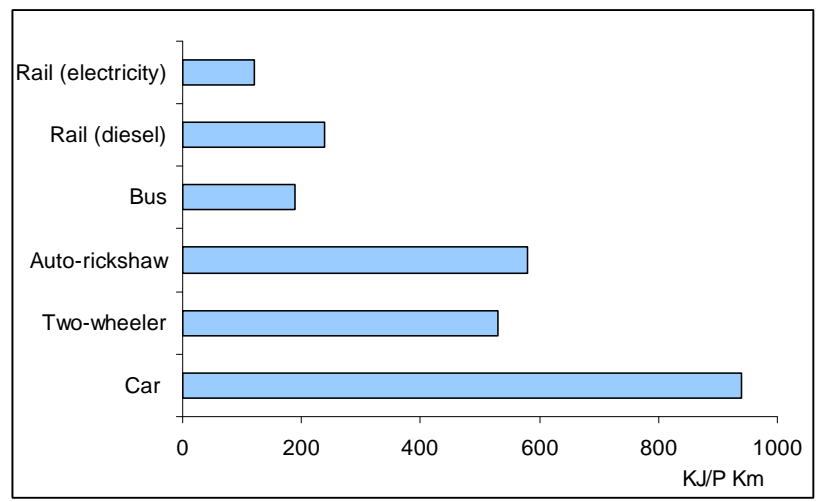

Figure 4 Energy Intensity in different transport modes in India (source: Singh 2006)

Currently, the private vehicles (passenger LDV) ownership in India was only 6per 1000 person in $2005{ }^{8}$, far lower than that in rich countries such as United States (710) and OECD- Europe (424), as shown in Figure 5.

\footnotetext{
${ }^{8}$ The primary reason for the extremely low LDV ownership in India is explained by the unproportionally high share of two- and threewheelers in the vehicle fleet. In 2005, two-wheelers represented over $80 \%$ of total passenger vehicles in India (Reddy and Balachandra ,2010)
} 


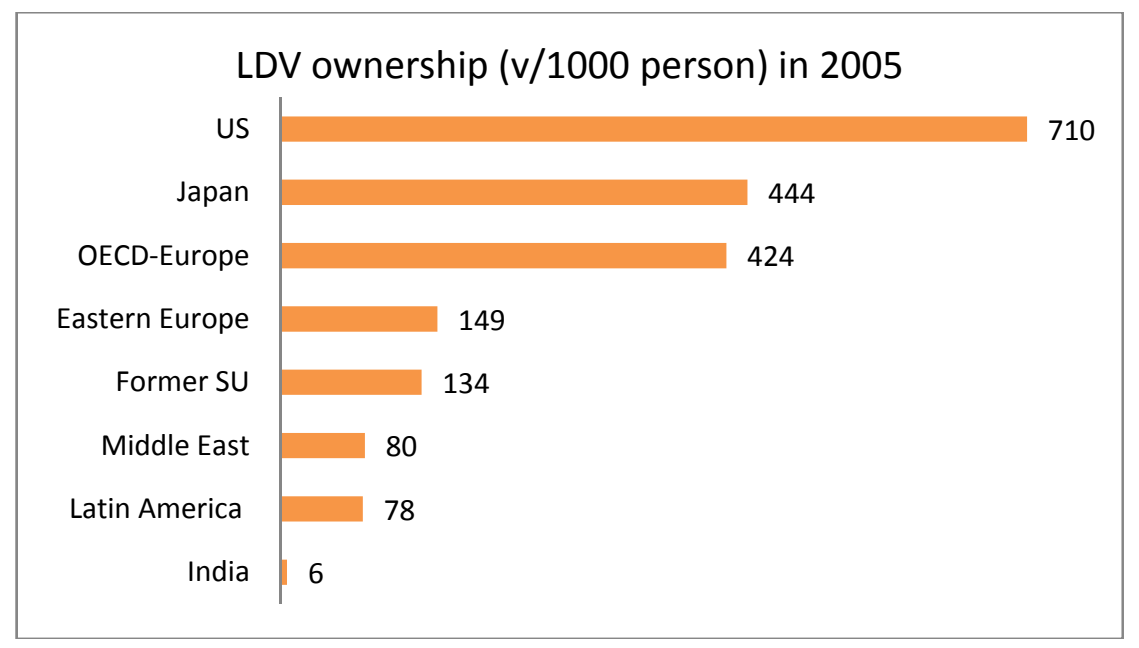

Figure 5 passenger vehicle ownership in different regions (IEA 2009)

Not surprisingly, high aspiration to private car ownership is expected in developing world, there is an increasingly persuasive picture of international lifestyle in which a car is an essential element (Gakenheimer, 1999). More recently, automobile ownership growth rates are of the order of $15-20 \%$ per annum in most Indian cities (Reddy and Balachandra, 2010). In developed countries, the empirical study of Karathodorou et al. (2010) found that higher costs of cars tend to favour more frequent use across the households.

However, constraints on urban density and supply of high-quality public transport can effectively restrain the car use even the households intend to purchase or have already possessed a car. Public survey shows that even in cities with high-density and good quality public transit system such as Singapore and Hong Kong, the car ownership is still quite low ( 57 cars for 1000 people in Hongkong and 99 cars per 1000 people in Singapore in 2005) compared to most high-income cities, albeit the majority of commuters using public transport still declared having intention to buy a car in the future (Poudenx, 2008). NMT (walking and cycling) and PT represent $82 \%$ and $46 \%$ of transport modal split in Kong Kong and Singapore, respectively. In addition, even in high car ownership country like France, PT and NMT still account for more than half of transport modal split in cities with well-organised public transit infrastructure such as Paris. By contrast, only less than 5\% of urban transport is carried by PT and NMT in the city of Huston (UITP 2001 ). Given its extremely low level at current stage, car ownership in Indian cities will certainly increase as resident's income rises, note that in some large metro cities in India, car ownership is significantly higher than the average in cities, 74 cars/1000 person in Delhi compared with 7 cars per 1000 people in the country. However, high-efficiency and good quality public transport can discourage the purchase desire and reduce the frequency of private car use for the daily commuting purpose in cities.

Another instrument of controlling the anarchic increase in car use in Singapore is the implementation of the car license plate auction system which requires the certificate of entitlement(COE) for new cars registration, similar COE system has also been implemented in the city of Shanghai in China. However, political leadership, sound institutions and available high-quality public transit systems are prerequisite of successful implementation of the COE or similar instruments ${ }^{9}$.

\subsection{Underdevelopment of efficient public transit}

Urban transport in most developing countries are characterised by higher ridership of public transit in urban mobility compared with the automobiles-dependent countries such as the U.S cities, most urban trips are carried by public transport in developing cities, in particular by buses. Majority of urban mobility is being carried by buses in Indian cities, as shown in Figure 6 and documented in Singh (2006) and Reddy and Balachandra(2010).

\footnotetext{
${ }^{9}$ Note that the experiences in some developing countries show that implementing licence plate issuance restriction ( caps or auction) to reduce private car use may encourage the development of black market of license plate and overused secondhand cars in the case of inappropriate design and institutional weakness.
} 
However, this apparent high ridership disguises the fact of low quality service provisions. For instance, in large Indian metropolitan cities such as Mumbai and Chennai, transit systems are characterised by overly used bus systems of very poor standard and lack of good quality of rail systems. The massive transit system in these cities is seriously underperforming as a result of much lower levels of services compared to that in high-income cities (e.g. Japan, France $)^{10}$.

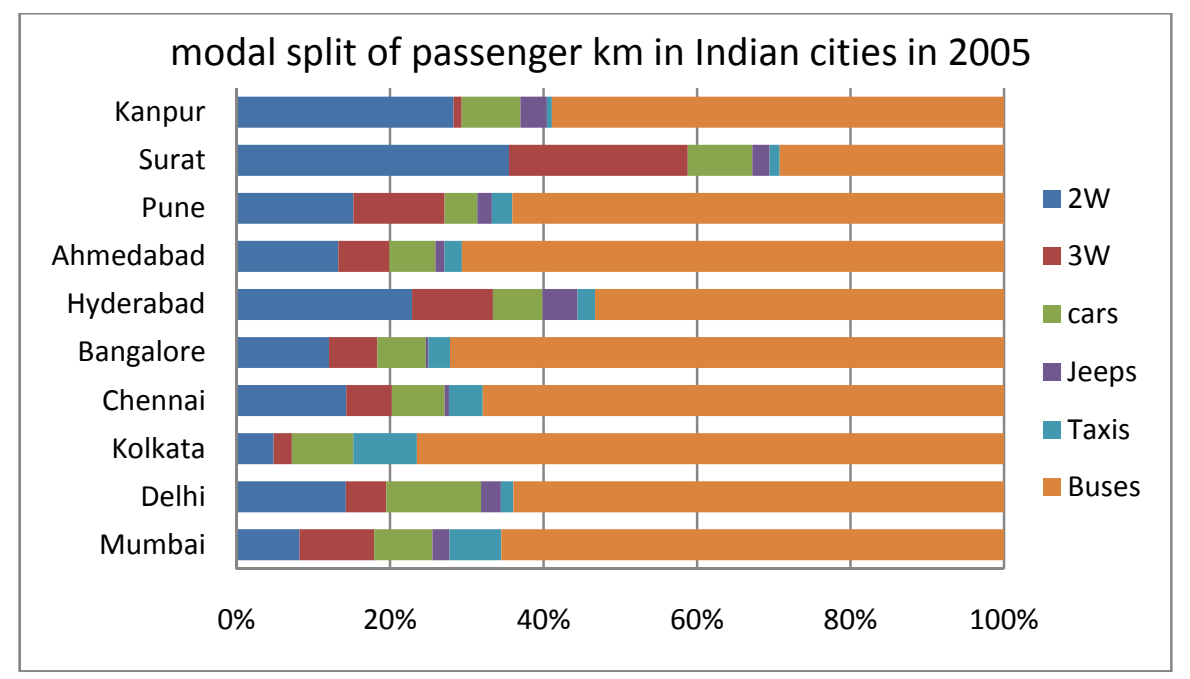

Figure 6 various modes of passenger $\mathrm{km}$ in large Indian cities

Source: Reddy and Balachandra(2010)

As in most developing countries, there exist various alternative modes of public transport on the streets in Indian cities and they present difficulties of efficiency and safety (Gakenheimer, 1999). Public transport is often underdeveloped and fails to meet the fast-growing demand in the absence of integrated urban transport management. Public transport in Indian cities as a whole grew modestly compared with private cars and motor cycles, and there is decline in public-private transport ratio for all the cities in the during the period 1981-2005 (Reddy and Balachandra, 2010). During the period 1981-2006, two-wheelers increased at an average growth rate of $24 \%$ per year, whereas bus grew only $13 \%$ per year and its share in total population of vehicles kept declining. In 2006, buses only account for $1 \%$ of total motor vehicles in India (MRTH, 2009) ${ }^{11}$.

Moreover, a large share of buses (88\%) is operated by small private companies. Development of efficient public transport infrastructure such as mass transit system (e.g. metro, BRT) in many Indian metropolis lags largely behind the spectacular urban growth. For example, Delhi , a city with a population of 17 million, has not seen metro (Delhi Mass Transit System) operating until 2002.

\subsection{Urban transport and externalities}

Ambient air pollution, though improving dramatically, remains a serious health problem in many cities in developing countries like India. According to UNEP, urban air pollution is estimated to cost approximately 5-20\% of GDP in developing countries. And more specifically, over $90 \%$ of air pollution in cities in these countries is attributable to vehicle emissions brought about by high number of older vehicles coupled with poor vehicle maintenance, inadequate infrastructure and low fuel quality (UNEP, 2005). Indian government estimates that environmental degradation costs $4.5 \%-5 \%$ of the country's GDP and $70 \%$ of air pollution is attributed to vehicle emissions (World Bank, 2008). Air quality is worse in the large metropolitan cities like Kolkata, Delhi, Mumbai, Chennai, etc. The city of Delhi started to implement an initiative of moving public transport to compressed natural gas (CNG) in 2001, ant this contributed to substantial improvements of local air quality and reduction in ambient air concentration of pollutants such as CO, SO2, suspended particulate matter (PM) and NOx (Goyal 2003). However, massive fuel-switch to natural gas from diesels in Indian cities would raise the concerns about the security of energy supply. Demand-side management of transport should also be considered to succeed in air pollution alleviation in urban areas. Further, switching to CGN in public transport only solves part of the problem of the increase in $\mathrm{CO} 2$ emissions.

${ }^{10}$ I thank one anonymous referee for pointing out this issue.

${ }^{11}$ Buses and rail still account for over two-thirds of urban mobility in Indian cities (Singh, 2006). 
Congestion is another serious problem in Indian cities. In Mumbai and other metropolitan centres, roads are often severely congested during the rush hours. The dramatic growth in vehicle ownership - at some 15 per cent a year during the past decade - has reduced rush hour speeds to 5-10 km an hour in the central areas of major cities (ADB, 2006), and this extremely low speed of motorised vehicles indicates the necessity of developing NMMs in Indian cities to diversify the transport modes and increase the mobility fluidity. The costs of congestion are very high in cities. Estimates of external costs show that other externalities have higher values than those for $\mathrm{CO}_{2}$ or energy dependence. Congestion externalities can be more than 10 times higher, air pollution and accidents externalities over 3 times higher (Harrington and McConnell, 2003). Indeed, many of the policies to reduce the externalities (congestion, noises, pollution, etc) also benefit climate and their value is enhanced (Goodwin, 2008).

Besides roads congestion, traffic accidents, public health incidence and air pollution, sharp increase in road transport has huge impact on fuel consumption and GHG emissions. Schafer and Victor (1999)'s study on carbon emissions from global transport suggests that in developing countries automobile travel is still rising and becomes the dominant source of carbon dioxide from passenger transport up to 2050.

Newman and Kenworthy (2006) indicate that contrary to industralised countries,

vehicle and fuel technology improvements have not been able to hold overall ambient air pollution levels steady or reduce them with increase in driving in cities in most developing countries. The pollution is even more important in these

high-density cities like Delhi, Mumbai, Kolkata , where air pollution threatens the health of millions . Most traffic consists of M2W(which form the bulk of India's motor vehicle fleet) and M3W with two-stroke engines. These transport modes are cheap to run but highly polluting, contributing to high-level urban air pollution. Surveys in the city of New Delhi in the mid-1990s showed 24-hr average PM levels exceeding World Health Organization (WHO) guideline limits almost daily, with peak levels as high as 6-10 times the limit at many sites. Pollutants concentration levels at ITO traffic intersection (where emissions are predominantly transport generated) are significantly higher than residential areas. The transport-caused urban pollution thus generates adverse socioeconomic, environmental, health, and welfare impacts (BADAMI, 2005 )

By contrast, high-quality urban transport can contribute to strengthening city's cohesion and facilitate people's work and living in the cities. Cities need good connections to inter-urban and long distance networks. They also need to ensure clean, efficient and affordable intra-urban mobility. The issue is particularly complicated in fast-growing economies where many people are still deprived of efficient urban transit and mobility infrastructure. Well-organized public transport is more efficient in term of carbon emission per passenger for the same distance travelled by a passenger, as can be seen from Figure 7, public transport can save considerable $\mathrm{CO}_{2}$ emissions for the same travel distance as compared to private travel modes.

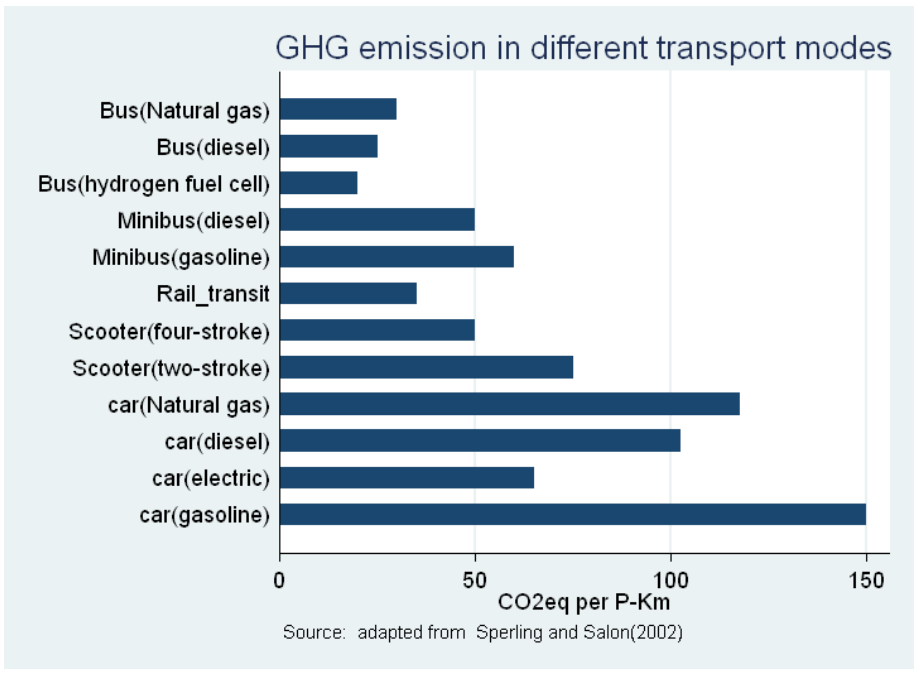

Figure 7. $\mathrm{CO}_{2}$ emission in different transport modes

A comparative study carried out by Das and Parikh (2003) puts emphasis on the role of enhanced public transport in containing energy consumption and GHG emissions in urban transport in India. Their simulations show that if the current trend continues, Mumbai would consume 60\% less fuels for transport than Delhi in 2020 
in spite of higher per capita GDP and similar city size and population thanks to more efficient and better developed public transit system (higher share of public bus transport and suburban railway system in Mumbai).

\subsection{Institutional weakness and lack of political willingness}

A large number of individual motor vehicles such as two-wheelers and auto-rickshaw results in scattered, diffused and difficult-to-target emission sources. As a consequence, local authorities are incapable of implementing high-efficiency and environment-friendly transport policies. In words, the anarchic development of private cars, M2Ws and M3Ws in cities will render the integrated management of urban transport nearly infeasible. The misallocation of financial resources may result in very negative impact on the urban transport quality and efficiency. A number of bad examples of laissez-faire of leadership of public infrastructure and irrational increase in private vehicles with deteriorated quality of public transport in many developing cities (e.g. Cairo has invested heavily in building modern expressways whilst the trams were finally left rotting and dysfunctional and derail regularly, Calcutta has similar example) show the policy contradictions in transport infrastructure due to bad governance. The weak institutional capacity of infrastructure governance and lack of political courage will encourage the bloom in private cars in cities and lead to a vicious circle- lower financial capacity in public transit system development and improvements ; reduced supply and deteriorated quality of public transport and encourages further usage of private cars and other motor vehicles. In reality, the lack of institutional and financial capacity in transport infrastructure is one of the direct results of the underdevelopment of public transport in many Indian cities. This can only be solved by setting strong political willingness in urban transport policy making to overcome the private lobby's pressure.

\section{Policy tools for climate resilient transport in Indian cities}

\subsection{Enhancing urban governance with improved policymaking process}

The comprehensive policy packages that contribute to integrating high-quality services of public transport consistent with sustainable urban development strategy have to be put in place, they should include combined land use and transport planning, fuel efficiency and public transit infrastructure improvements, economic instruments, political relevance and institutional change. Indian cities are undergoing fundamental change in terms of simultaneous demographic, technological and socioeconomic transition on a par with the rapidly evolving urbanisation process, the interplay between socioeconomic development (poverty reduction, educational, security and public health improvements) and urban infrastructure (housing, energy , transport) and environment (air quality, sanitation, climate change) underlines the necessity of enhancing the urban governance in Indian cities to address the pressing challenges.

All these aspects can only be touched upon effectively within a sound framework and step-by-step policymaking process. As policymaking in urban transport is a complex and time-consuming process, each step must identify relevant aspects with regard to urban transport's role in city's comprehensive development strategies and involve the stakeholders of interest, process should be made as transparent and efficient as possible to avoid misunderstanding and overlapping as well as over-influence of interests groups lobbying.

Good governance can also help improve the resilience and adaptive capacity of cities in the events of unpredictable dysfunctions of transport systems (e.g. traffic chaos, congestion...). In fact, policies under question must incorporate urban development priorities, climate change mitigation and adaption programmes setting, relevant instruments design, implementation, monitoring and assessment. In addition, the credibility of public policies is critical to creating synergy between different stakeholders including the local residents, it is also a necessity in ensuring the liveability of implemented programmes in the longer term. Urban governance is critical to guaranteeing the appropriate functioning of the policies and instruments envisioned.

\subsection{Improving quality and image of public transit}

Improvement in public transport services and lower commuting costs (including time value) of PT reduce effectively the use of private cars and subsequently the fuel consumption, which is confirmed by Karathodorou 
(2010). However, larger number of commuters in the mass transit system implies deterioration of travel comfort due to the crowding effect. Thus improving the service quality of public transport is a necessary condition for car users to make modal shift in urban commuting as the direct control on cars often fails given the experiences in developed countries (Poudenx, 2008).

Like many rapidly industrialising countries, decision making of public goods such as PT is strongly influenced and lobbied by interest groups at the expense of concerted public debates and transparency in governance. Communities of interests stand to benefit greatly from road construction, as well as political favours to be gained from pandering to well-to-do population. It is then observed frequently that considerable investments have been channelled to build new road infrastructure whilst public transport always lack money in cities. To overcome the contradictions, strong political will and policy leadership are required to channel the limited financial resources to improve dramatically the public transport infrastructure in cities.In this respect, urban governance in the public transport sector must be strengthened to allocate resources more efficiently. This will help encourage the development of more efficient rapid transit systems to attenuate the sharp growth of individual cars and other alternative transport modes in the large cities without necessarily reducing the mobility demands of commuters. It can also change the perception of public transit by commuters and local residents.

Specifically, the vast majority of public transport in developing world is private and most of them are made up of relatively small scale concessionaires each serving a limit number of routes and competing with one another (Gakenheimer, 1999). The situation in India is quite similar as most of buses (88\%) are run by private companies (MRTH, 2009). Institutional changes should be undertaken in order to enhance the public-private partnership and increase the role of public transport in urban areas, in particular the bus-based public transport, since the rail-based transit systems like metro or subways is economically only viable in highly-dense cities with concentrating employment and large working population.

\subsection{Reconciling transport services and urban development and energy security}

Transport should be regarded as an essential and organic component in shaping high-quality urban life in Indian cities. Living condition in cities is determined by various factors as well as their interplay. Transport is believed to play a networking role to relate the urban residents' social and professional networks to the underlying urban structure. Public policy is supposed to make urban transport development compatible with the cities' long term economic and urban development objectives. Transit system should be designed not merely as a means of transporting passengers from point $\mathrm{A}$ to $\mathrm{B}$, but to be integrated in the urban mobility structure such that transit can be appreciated by and convenient for users. However, transport planning is quite often designed separately by individual authority, constant interaction and cooperation with other urban services is crucial for transport quality improvement. Additionally, local government should work more closely with corporate, NGOs and other local organisations to raise the awareness of economic, energy and environmental benefits and social responsibility of riding public transport and other alternative transport means such as cycling, car-pooling and walking. Practice of public-private partnership in public transit in some western countries may be a good lesson for Indian cities. For instance, Paris's local government imposes on both public institutions and private firms a $50 \%$ reimbursement of monthly pass for employees commuting with public transport. More generally, transport policy can be integrated into the corporate social responsibility (CSR) schemes in cities in favour of raising funding for improvements in public transit systems and public debates in low carbon transport strategies.

In addition to urban life and environmental quality improvement, high-level public transport also allows policymakers to integrate transport in the energy and climate policy making, since increased use of public transit and reduction in private vehicles can significantly mitigate the vulnerability of the dependence on imported oil as well as GHG emissions. This is crucial from macroeconomic development perspective, all economic studies shows that high dependence on oil will significantly effect GDP growth as it is more exposed to the risk of price volatility. Oil price spike may also generate inflationary growth of commodities that again affects the long term growth of economies. 


\subsection{Integrated transport management/ land use planning and public transit finance}

An integrated approach that combines spatial planning, transport and urban planning, land market governance and environmental policies is particularly compelling due to the interplay between sectors in the development process in cities. As experienced in developed countries, spatial planning influences transport variables much more than transport policy itself under certain circumstances. Integrating land use policy with decoupling objectives in the transport sector is important. Changes in land use regulations may be needed to provide incentives for mixed-use areas with high-density (OECD, 2008). Cities must be aware that various land use factors such as density, regional accessibility, mix and roadway connectivity affect travel behaviour, including per capita vehicle travel, modal split and non motorised travel. Thus relevant transport and urban planning tools can be designed to discourage the unnecessary trips by private cars. In this regard, it is more reasonable that Indian cities follow Japanese experience instead of the North American cities with regard to the urban growth pattern $^{12}$.

Modal split between different transport modes, including non-motorised mobility is a fundamental element in the transport planning and management in cities. For instance, Kenworthy and Hu (2002) point out that in cities in fast-growing countries (they studied Chinese cities as illustrative example, the postulate also applies to the Indian cities), it is essential to implement road sharing policies to accommodating growing numbers of motor vehicles while allowing non-motorised modes of transport to continue to flourish in safety and contribute to energy savings, air pollution and noises reduction and public health.

Public policies are needed to restrict excessive car use in favour of high-quality public transit system in Indian cities. Some experiences can be learnt from other Asian cities such as Singapore and Hong Kong which put in place a comprehensive TMD measures: high purchase tax and licence registration fees (vehicle quota system), road use restriction, Area Licensing Zone which restricts the access to CBD is combined with high taxes and parking fees, road pricing system (Poudenx, 2008). However, putting place these instruments requires significant political courage when facing the lobbying of interest groups such as oil companies and road constructors. Also, technical expertise and human capital must be available to allow for smooth implementation of relevant policy instruments.

In addition, lack of financial capacity often constitutes a major barrier to developing efficient public transit system. The integrated transport and land use planning may also provide sustainable financial resources. The value capturing financing (VCF) may be considered one of means to bridge the gaps in urban infrastructure finance. Incremental value due to land improvements can be recouped to finance public transit. In general, VCF can create incentives to improve urban infrastructure, encourage better development, curb land speculation, prevent land price spirals and distortion in land supply, curtail urban sprawl, and promotes affordable land access. The betterments tax in Hong Kong MTR financing is a good example of public-private partnership in urban transit system financing via VCF mechanism. Other useful experiences in both developed and developing countries can be learned by Indian local governments. However, the VC approaches require a priori good governance in urban land including property assessment and transactions market transparency as well as adequate coordination between institutions concerned at both regional and local levels.

\subsection{Traffic management, fuel efficiency and carbon indicators in transport}

Improvements in traffic management can increase the probability of better traffic fluidity and reduce road congestion, fuel consumption and related GHG and pollutant emissions. This can be done by improving infrastructure quality and optimising traffic management supported by ITS technologies. Aggressive improvement in fuel efficiency and standards stringency can also reduce fuels consumption per unity of distance travelled and make substantial contribution to reducing fuel consumption and related GHG and polluting gases emissions, Energy efficiency and emissions standards of new vehicles (both domestically manufactured and imported ) must be tightened to favour penetration of greener and low-emission vehicles and accelerate the phase-out of old inefficient cars on roads. Indicators of energy and carbon performance are to be generalised to better inform the consumer when purchasing transport related services. Strong public policies are required to support the efficiency improvements programme in the car industry. Similar regulations are also needed in the

\footnotetext{
12 Japan's urban areas are around five times denser than Canada's, and the use of energy per capita in Japan is around 40\% that of Canada's ( OECD 2009).
} 
two- and three-wheeler motors as well as other motor vehicles. Radical improvements in diesel-fuelled vehicles is of extreme importance as most vehicles in India are powered by diesels (IEA, 2010).

Another market-based approach for accelerating fuel efficiency improvement is to introduce the mandatory or voluntary labelling in the transport sector. Energy labelling is one of useful policy instruments to pull car industry towards high-efficient market. For example, various 'energy efficiency', 'environment-friendly' and 'low-carbon' labelling schemes for other sectors such as buildings (in particular the norms of electric appliances performance) have been successfully introduced in both developed and developing countries, including India's Standard and labelling programme (regulating equipment energy efficiency), launched by the bureau of energy efficiency of Ministry of Power in 2006. Similarly, car efficiency (fuel efficiency and carbon emission) label could be introduced in the car market in India with adaptive scheme to local context. This will help accelerate the penetration of high-efficiency and low carbon vehicles in the market and scrappage of low-efficiency fleets.

\subsection{Rethinking cost-benefits analysis and economic instruments}

Robust cost-benefits analysis must be undertaken systematically by including the social, environment and climate external effects into account in the urban transport projects investment assessment based on LCA approach. This evaluation method will uncover the hidden costs of private vehicles and reveal the comparable competitiveness between different urban transport modes, consequently public transit turns out to be more performing in terms of financial return on investment. Moreover, it is useful to conduct multimodal transit ridership with a varying fare structure in urban transport planning process.

The transport-related problems must be addressed holistically by combining different technologies and policy instruments in the context of developing world (Komor et al., 1993), such as financial incentives and discriminatory pricing. These means can allow changing existing travel behaviour patterns and modifying urban development patterns to minimize the type, length, and frequency of trips that people need to take (Lohani, 2007). One of effective policy instruments in climate policy in the transport sector is to put a price on carbon to make final consumers change gradually consumption behaviour and lifestyle towards a more climate friendly way.

A survey of literature shows that gasoline tax turns out to be more efficient than subsidy on public transport to contain excessive urban spatial expansion and to discourage private car use. Apart from the urban form which determines the demand for private and public transport, economic instruments turn out to be an important factor even between the high-income countries. The significant difference of car use and gasoline consumption between US and European cities is partly due to the tax differentials. Empirical works show taxation on fuel use did encourage fuel economy and reduce travel by cars and related fuel consumption in OECD countries (Johansson and Schipper, 1997'13). This is also confirmed by the difference between European and US cities' fuel consumption. Sterner(2007)'s analysis shows that Europe's fuel consumption would have been twice as high if hypothetical American tax level had been implemented. He argues that fuel taxation has been the most powerful climate policy instrument although often neglected. As demand for private cars is likely to increase rapidly in industrialising countries like India over the next decades, implementing appropriate fuel tax can help discourage private vehicle use in these cities.

More specifically, price elasticity is found to increase as price goes up. Fiscal policies (e.g. individual and corporate tax credit) turn out to be an efficient way to incentivise people to purchase and use more energy efficient and carbon-saving vehicles, or discouraging urban residents to use private car for commuting through tax instruments (parking, congestion charge or road pricing in London and Singapore for example, car license and plate registration fees and carbon tax etc). However, as in the case of financing public transport, politicians may encounter lobby and obstruction if they decide to impose fuel tax. One important issue is that politically speaking, it is quite difficult to impose high fuel tax to induce people to change their lifestyles in the sprawled cities (Hammer et al. 2004) . Therefore, implementing tax on gasoline or diesel should be assessed in conjunction with urban planning in the Indian context, it would be too late (as the case in the US) to impose tax once the cities have already been sprawled and large fraction of urban resident live far away from city centre and commute by private vehicles, only $5 \%$ of the commuters use public transit as their usual mode to work in the US ( DOT 2004).

\footnotetext{
13 What Johansson and Schipper (1997) show is that the effects of changed taxes on car ownership and use are significant, but smaller than from a change in fuel tax based on an econometric analysis in 12 OECD countries from 1973 to 1992.
} 
Indeed, to make fiscal instruments effective, it is extremely important to have insight into households' consumption behaviour, the utmost indicators are income and price elasticities. Most studies show that shortand long-term gasoline demand is generally income elastic and price inelastic, in particular in developing economies (Garbacz, 1989; Dahl and Sterner 1991, Eltony \& Al-Mutairi, 1995; Ramanathan, 1999; Cheung and Thomson, 2004; Cao, 2009). More specifically, income elasticity in developing countries is found much higher than that in developed countries (McRae, 1994). Again this highlights the importance of urban form, poor households living in far suburb are obliged to commute by car and will need to spend a significant part of their income in transport in sprawled cities.

Ramanathan (1999)investigates the income and price elasticities of gasoline demand in India based on cointegration analysis technique and shows that the gasoline demand has a high long-run income elasticity of 2.68 and low LR price elasticity of -0.32 (Ramanathan, That implies demand for gasoline would increase more rapidly than economic growth pace pattern (which determines the household income level) under the current development. In fact, the low price elasticity can be explained in part by the fact that motor fuels, diesels and other petroleum products in India are heavily subsidized by the government, fuel subsidies amounted to around 12.7 billion USD in 2008 (IEA, 2010). The government bears huge burden of energy subsidies in particular in the agriculture sector (diesels account for the majority of agricultural vehicles fuels).

The energy subsidy in private transport in India will not favour the rapid and large-scale development of high efficient public transit and low carbon transport. Fuel tax, and eventually a carbon tax, might be levied on car and motor vehicle use. Tax revenue can then be redistributed to low-income families in cities and compensation and premium to using public transport. Importantly, Sterner et al.(2010) stress that the distributional effects should not be used as an excuse to prevent low-income countries from implementing gasoline tax since they turn out to be progressive, instead of being regressive in many cases in developed countries (People driving cars are generally well-to-do in developing nations) ${ }^{14}$. This can be confirmed by the fact illustrated in the introductory section which showed the significant gap of per capita car use in India, since only wealthy people living in urban zone can afford to buy and drive a car. Cao (2009)'s empirical study in China strongly underlines this argument. Indeed, public transport and other low carbon alternative travel means must be adequately existing if gasoline or carbon tax are to be put in place in Indian cities, otherwise people (in particular the low income households) may be trapped with high energy costs in the absence of alternatives. Imposing tax cannot be seen as a target to restrain people's mobility but rather a means of redistribution for more balanced investments in transport infrastructure.

If Indian government continues to subsidise energy for private car use, more and more people will try to purchase automobiles and live far from city center with increased income, and eventually cities will expand and sprawl as experienced in the US cities, and then it would be too late for the government to control the situation once the sprawl has been created. Therefore fiscal policy and urban planning must be combined to address the urban transport challenge. In addition, comprehensive road-pricing instruments for dealing with road transportrelated externalities such as mileage taxes, road tolls, differentiated vehicle taxes scheme, combined with integrated urban planning strategies, can be designed in integrated manner. Lessons can be learned from cities in high-income countries such as Singapore, Stockholm, Yokohama which all have good practices and successful experiences in integrated urban sustainability management (Suzuki et al., 2010), as well as developing countries (e.g. Curitiba ${ }^{15}$ ), and policymakers should allow for the concurrent operation of different fee systems.

\footnotetext{
${ }^{14}$ It should be noted that the transfers aiming at improving public transport services will contribute to reducing social inequality by reducing the transport segregation (rich people use private cars whilst poor people have to struggle in crowded buses in the absence of strong public policy interventions).

15 Curitiba in Brazil is one of the most noticeable cases with regard to integrated transport and land use management: the platoon of grouping buses, the boarding station enabling prepayment of the fare. Local government of Curitiba has succeeded in organizing residents' travel by favouring rapid bus transit system; thanks to a comprehensive master plan of land use in the 1960s, which has been subject to virtually no change over the period. However, Curitiba's experience was inscribed in its unique political background, how to make similar policy instruments (dictatorial style land use restriction) more relevant in the broadly democratic political regime such as India poses challenges in terms of implementation.
} 


\section{Conclusions and perspective}

Our review provided an overview of debates relating to urban transport governance in Indian cities. Controlling GHG emissions without hindering economic development is a daunting challenge for the world in this century, in particular in rapidly industrialising and urbanising countries like India, for which the priority is economic development, poverty reduction, improvements in living standard and social welfare. Unchecked growth of private vehicles and inappropriate development of transport infrastructure in the metropolitan cities will have significant implications for resource depletion and global warming in the future. The decisions made on infrastructure's performance to date have definite impact on energy demand and GHG emissions trajectories for a longer term, and low efficient transport infrastructure risks the technological and carbon lock-in as a result of strong inertia and limited capital available in developing cities.

Realising GHG reduction in the urban transport can not be achieved without institutional coordination and relevant policy tools. Also, progress towards low-carbon transport requires effective partnerships and involvement of a wide range of stakeholders. urban transport infrastructure governance should be strengthened by articulating transport policy with urban development plans in relations to land resource allocations. Local authorities in Indian cities can draw some useful lessons from past experiences in the world to implement public policies supporting integrated land-use and transport infrastructure management, based on a multi-tier approach ; 1. Promoting vigorously public transport infrastructure (e.g efficient buses such as BRT, rail-based mass transit systems) through enhanced urban transport management and ambitious political leadership; 2. Improving policymaking of public transport and urban infrastructure investments based on an transparent and rigorous assessment of costs and benefits; 3; Instituting land use regulations and land market in favour of investment in efficient public transit, increasing urban density to mitigate the urban sprawl tendency and subsequent private car use; 4. Implementing economic instruments such as sophisticated road pricing, parking and vehicles license fees as well as fuel tax to redistribute the financial resources and increase the efficiency of public transport with minimised market distortions.

In perspective, our critical review emphasises the importance of undertaking an integrated approach to dealing with urban transport-induced GHG emission, such as comprehensive urban planning, road pricing, and optimised land use mixture in cities. Meaningful and penetrating efforts should be centred on the creation of specific mechanisms in favour of comprehensive partnership between public institutions and private sectors to accelerate transition to low carbon transport in Indian cities.

\section{References}

Asian Development Bank (ADB), 2006. Energy Efficiency and Climate Change Considerations for on-road Transport in Asia.

Auffhammer,M and Carson, R. 2008. Journal of Environmental Economics and Management, Vol. 55(3), pp. 229-247.

Azomahou T., Laisney F., Nguyen-Van P. (2006), "Economic development and CO2 emissions: A nonparametric panel approach", Journal of Public Economics, 90(6-7), 1347-1363.

Baltagi, B. and Griffen, J. 1983. "Gasoline demand in the OECD: an application of Pooling and testing procedures ”. European Econ Rev, 22, pp.117-37.

BADAMI,M.2005. Transport and Urban Air Pollution in India. Environment Manag. Vol 36 (2): 195-204, 
Bento, A.,Cropper, M., Mobarak, A. and Vinha, K. 2005. The Effects of Urban Spatial Structure on Travel Demand in the United States. Review of Economics and Statistics, 87(3): 466-478

Bentzen, J, 1994. "An empirical analysis of gasoline demand in Denmark using cointegration techniques" Energy Economics, , vol. 16(2), pp.139-143

Bose, R. et al. 2001. 'Transportation in Developing Countries - GHG Scenarios for Delhi. Report prepared for the Pew Center on Global Climate Change.

Bose, R. 2006. Transport Sector and Climate Change in India: Forecast and Policy Recommendations . Proceedings presented at Regional Workshop on “Climate Change Mitigation in the Transport Sector”. Asian Development Bank, Manila.

Brueckner, J. (2005) Transport subsidies, system choice and urban sprawl. Regional science and urban economics. Vol. 35 (6): 715-733

Button,C. 2004. Alternative approaches toward containing transport externalities: An international comparison Transportation Research Part A: Policy and Practice, Volume 28,(4):289-305

Bureau of Transportation Statistics (BTS).2010. National Transportation Statistics

Burton, E. (2000) . The compact city: just or just compact? A preliminary analysis, Urban Studies 37 (11) (2000), pp. 1969-2001.

California State Government. 2007 California State Government White Paper. The Role of a Low Carbon Fuel Standard in Reducing Greenhouse Gas Emissions and Protecting Our Economy http://gov.ca.gov/index.php?/factsheet/5155/

Cao, J. 2009. Is Fuel Taxation Progressive or Regressive in China? Paper presented at the FEEM summer school 2009. Venice, Italy.

Chiu,Y., Walseth,B. and Suh, S. 2009. Water Embodied in Bioethanol in the United States. Environ. Sci. Technol., 43 (8), pp 2688-2692.

Colvile, R. , Hutchinson, E., Mindell, J. and Warren, R. 2001. The transport sector as a source of air pollution. Atmospheric Environment, Vol.35 (9), pp. 1537-1565

Crane, R., 1999. The Impacts of Urban Form on Travel: A Critical Review. Working paper, Lincoln Institute of Land Policy, Cambridge, MA.

Chen, H., Jia, B. and Lau, S. (2008). Sustainable urban form for Chinese compact cities: Challenges of a rapid urbanized economy. Habitat International, Vol.32 ( 1), pp. 28-40

Cheung, K. and Thomson, E. 2004. The demand for gasoline in China: a cointegration analysis. Journal of Applied Statistics, Vol. 31(5), pp.533-44

Dahl, C. A. and Sterner, T.1991. ‘Analyzing gasoline demand elasticities, a survey” . Energy Econ.13, pp.20310.

Das, A. and J, Parikh. 2004. Transport scenarios in two metropolitan cities in India: Delhi and Mumbai. Energy Conversion and Management. Vol. 45 (15-16), pp. 2603-2625

Department of Energy (DOE), Washington. US. EIA. International Energy Outlook.( 2006). DOE, Washington. Energy Issues, 24 (3/4). 
Department of Transportation (DOT). 2004. 2001 National Household Travel Survey. Summary of Travel Trends

Economists, Car ownership on the road. 2009-1-9.

Eltony, M. \& Al-Mutairi, N. 1995. Demand for gasoline in Kuwait: an empirical analysis using cointegration techniques. Energy Economics, vol. 17(3), pp. 249-253

FAO 2003. State of the food insecurity in the world. Roma: FAO

Fortman JL, Chhabra S, Mukhopadhyay A, Chou H, Lee TS, Steen E, Keasling JD. 2008. Biofuel alternatives to ethanol: pumping the microbial well. Trends Biotechnol. 26(7):375-81.

Garbacz, C.1989. Gasoline, diesel and motor-fuel demand in Taiwan, Energy Journal, 10(2), pp.153-163

Gakenheimer, R. 1999. Urban mobility in the developing world. Transportation Research Part A: Policy and Practice, Vol. 33 (7): 671-689

Glaeser, E. And M.E. Kahn. 2004. Sprawl and urban growth. Handbook of Urban and Regional Economics, vol. 4. North-Holland, Amsterdam.

Goodwin, P., Dargay, J. and Hanly, M.2004. Elasticities of road traffic and fuel consumption with respect to price and income: a review. Transport reviews , Vol.24 (3):275-292

Goodwin, P. (2008).Policy Incentives to Change Behaviour in Passenger Transport.

Goyal, P., Sidhartha 2003. Present scenario of air quality in Delhi: a case study of CNG implemetation. Atmospheric envrionment. Vol.37(38): 5423-5431

Grazi, F., Van den Bergh, J. and van Ommeren,J.2008. An empirical analysis of urban form, transport and global warming. Energy Journal. Vol.29(4): 97-122.

Greening, L., Greene, D., Difiglio, C. 2000. Energy efficiency and consumption - the rebound effect - a survey. Energy Policy. Volume 28, Issues 6-7, pp. 389-401

Hammar, H., Lofgren,A. and Sterner, T. 2004. "Political Economy Obstacles to Fuel Taxation" Energy Journal, vol. 25(3), pages 1-18.

Handy, S. 2005.Smart Growth and the Transportation-Land Use Connection: What Does the Research Tell Us? International Regional Science Review; Vol. 28(2): 146-167

Handy,S. (1996). Methodologies for exploring the link between urban form and travel behavior, Transportation Research D 1 (2) (1996), pp. 151-165.

Harrington, W. and McConnell, V. (2003), Motor Vehicles and the Environment, Resources for the Future Report (April), http://www.rff.org/rff/Documents/RFF-RPT-carsenviron.pdf

Henderson, J. 2010. Cities and development. Journal of Regional Science. Vol. 50(1), pp. 515 - 540

IEA (2008), Energy Technology Perspectives In support of the G8 Plan of Action: Scenarios \& Strategies to 2050.

IEA 2006. World Energy Outlook. International Energy Agency. Paris.

IEA 2007. World Energy Outlook—China and India insights. International Energy Agency. Paris. 
IEA 2010b. Sustainable production of second-generation biofuels. IEA information paper. Paris.

IFPRI 2009. Global Hunger Index. The challenge of Hunger: Focus on Financial Crisis and Gender inequality. Bonn, Washington D. C., Dublin. 56 p.

IPCC 2007. Mitigation. Contribution of Working Group III to the Fourth Assessment Report of the Intergovernmental Panel on Climate Change.[B. Metz, O.R. Davidson, P.R. Bosch, R. Dave, L.A. Meyer (eds)], Cambridge University Press, Cambridge, United Kingdom and New York, NY, USA. 60 p.

ITF (2008), Greenhouse Gas Reduction Strategies in the Transport Sector, Preliminary Report. International Road Federation (IRF). 2009. World Road Statistics 2008 - Data 2001-2006.

Liverani, A.2009. Climate Change and Individual Behavior: Considerations for Policy. World Bank; World Bank Policy Research Working Paper No. 5058

Johansson, O. and Schipper, L. 1997. Measuring the Long-Run Fuel Demand of Cars. Journal of Transport Economics and Policy. Vol. 31, Part 3, pp. 277-292

JTRC/ITF/OECD (2008).Transport Outlook 2008: Focusing on CO2 Emissions from Road Vehicles. Discussion Paper No. 2008-13

Kasanko et al. 2006. Are European cities becoming dispersed. Landscape and Urban Planning. Vol.77(1-2), pp. 111-130

Karathodorou, N., Graham, D., Noland, R. 2010. Estimating the effect of urban density on fuel demand. Energy Economics $32(1)$ : 86-92

Kenworthy, J. 2003, Transport Energy Use and Greenhouse Gases in Urban Passenger Transport Systems: A Study of 84 Global Cities.

Kenworthy, J. R and Laube, F. 1999. International sourcebook of automobile dependence in cities.

Kenworthy, J. and Hu, G. 2002. Transport and urban form in Chinese cities: An international comparative and policy perspective with implications for sustainable urban transport in China, Sustainable Urban and Regional Development in China 2002 (4) , pp. 4-14

Knaap, G-J and Song, Y. 2004. The Transportation-Land Use Policy Connection; Prepared for presentation at the Conference entitled “Access to Destination: Rethinking the Transportation Future of our Region”.

Komor, P., Baldwin, S. and Dunkerley, J. 1993. Technologies for improving transportation energy efficiency in the developing world. Transportation Research Part A: Policy and Practice, Vol.27(5), pp. 359-372

Kuzmyak, R and Pratt,R. (2003), Land Use and Site Design: Traveler Response to Transport System Changes, Chapter 15, Transit Cooperative Research Program Report 95, Transportation Research Board

Litman, T. and Steele, R. 2008. Land use impacts on transport. Victoria Transport Policy Institute. 66 p.

Lonali, B. Director General of ADB’s Regional and Sustainable Development Department . Speech.

Martínez-Zarzoso, I. 2008. The Impact of Urbanization on CO2 Emissions: Evidence from Developing Countries. Climate Change Modelling and Policy. FEEM. 
Mckinsey. 2010. India’s urban awakening: building inclusive cities, sustaining economic growth.

Michaelis, L. and Davidson, O. 1996. GHG mitigation in the transport sector. Energy Policy. Vol.24(10):969984

Mindali, O., Raveh, A., Salomon, I. (2004), "Urban Density and Energy Consumption: A New Look At Old Statistics,” Transportation Research A, Vol. 38 (2), pp. 143-162.

Ministry of Roads, Transport and Highways of India (2009). Road transport yearbook 2006-2007. 240 p.

Modarres, A. 1993Evaluating employer-based transportation demand management programs. Transportation Research Part A: Policy and Practice, , vol. 27(4):291-297

Newman, P. and Kenworthy, J. 1988. The transport energy trade-off: Fuel-efficient traffic versus fuel-efficient cities. Transportation Research Part A: Vol. 22 (3): 163-174.

OECD. 2008. Environmental Outlook 2030. 517 p. Paris.

OECD.2009. Cities and Climate Change. Paris.

PricewaterhouseCoopers. 2010. Cities of Opportunity: a look at the world's hubs of finance, commerce, sustainability and culture. Pwc Report, 70 p.

Ramachandra, T. and Shwetmala. 2009. Emissions from India's transport sector: Statewise synthesis. Atmospheric Environment. Volume 43, Issue 34, November 2009, Pages 5510-5517

Ramanathan, R. 1999. Short- and long-run elasticities of gasoline demand in India: An empirical analysis using cointegration techniques. Energy Economics, Vol. 21(4), pp. 321-330

Sanderson, K. 2006. US biofuels: A field in ferment. Nature 444, 673-676 (7 December 2006) | doi:10.1038/444673a

Saunders, M., Kuhnimhof, T., Chlond, Bastian., Rodrigues da Silva, Antonio. 2008. Incorporating transport energy into urban planning. Transportation Research Part A: Policy and Practice, Vol.42 (6), pp. 874-882

Schafer, A. and D. G. Victor. 1999. Global passenger travel: implications for carbon dioxide emissions. Energy. Volume 24(8), pp. 657-679

Schneider, A. and Woodcock, C. 2008 Compact, dispersed, fragmented, extensive? A comparison of urban growth in 25 global cities using remotely sensed data, pattern metrics and census information. Urban Studies, vol. 45, pp. 659-692

Sharma et al., 2006. Greenhouse gases emission from India: a perspective. Current Science, vol.90(3):326-333.

Shim, G., Rhee, S., Ahn,K. and Chung, S. 2006.The relationship between the characteristics of transportation energy consumption and urban form. Ann Reg Sci 40:351-367

Short, J.2008. Transport and Climate Change Policies for harder times. Presentation at the Dublin Economic Workshop Policy Conference, World Transport Forum.

Singh, S. 2006. Future mobility in India: Implications for energy demand and CO2 emission Transport Policy, Volume 13(5), pp. 398-412 
Singh, A., Gangopadhyay, S., Nanda, P., Bhattacharya, S., Sharma, C. and C. Bhan. 2008. Trends of greenhouse gas emissions from the road transport sector in India, Science of the Total Environment, Vol.390(1), pp. 124-131

Somayajulu, U. and Mukherji, T. Urbanisation and Growth of Million + Cities in India, ppt presentation in the 4th International Conference on Population Geogra phies, Hong Kong. 2007.

Song,Y. and Zenou, Y. 2009. How do differences in property taxes within cities affect urban sprawl? Journal of regional science. Vol.49 (5):801-31.

Sperling, D. and Salon,D. 2002. Transportation in Developing Countries: An Overview of Greenhouse Gas Reduction Strategies, university of California, Davis.

Steen, E. et al. 2010.Microbial production of fatty-acid-derived fuels and chemicals from plant biomass. Nature 463, 559-562

Stern, N. 2006. Stern Review on the Economics of Climate Change. HM Treasury, UK.

Sterner, T. 2010. Distributional effects of taxing transport fuel. Energy Policy, Article in Press.

Sudhakar Yedla, Ram M. Shrestha. 2003. Multi-criteria approach for the selection of alternative options for environmentally sustainable transport system in Delhi. Transportation Research Part A: Policy and Practice, Vol.37( 8), pp. 717-729.

Suzuki, H., Dastur, A. Moffat, S.,Yabuki,N. and Maruyama,H. 2010. Eco2 cities : ecological cities as economical cities. World Bank. Washington, D.C. 392 p.

TERI 2005. Liquid Biofuels for Transportation: India country study on potential and implications for sustainable agriculture and energy. Report to GTZ.

Unger, N., Bond, T. Wang, J. , Koch,D., Menon, S., Shindell, D. and Bauer, S. 2010. Attribution of climate forcing to economic sectors. PNAS. vol. 107 (8): 3382-3387

Union Internationale du Transport Public (UITP). 2001. Millennium cities database for sustainable transport.

UNEP 2005. Urban Air Quality Management Toolbook. Nairobi. 55 p.

UN. World Population Prospects: The 2004 Revision. Population Division of the Department of Economic and Social Affairs of the United Nations Secretariat, 2005. Dataset on CD-ROM. New York: United Nations.

US Census Bureau.2009. International Data Base : demographic indicators.

http://www.census.gov/ipc/www/idb/country.php

Vance, C. and Hedel, R. 2007. The impact of urban form on automobile travel: disentangling causation from correlation. Transportation, Volume 34(5),pp.575-588.

World Resource Institute (WRI): Earth Trend Energy and Resources 2008. 